\title{
THE ECONOMIC RECOVERY ACT OF 1981 AND TAX' POLICIES FOR COMMERCIAL SOLAR-ENERGY APPLICATIONS
}

David E. Ball

December 1981

Prepared by

SOUTHERN SOLAR ENERGY CENTER

For

U.S. DEPARTMENT OF ENERGY

under contract DE-AC03-79CS30166 


\section{DISCLAIMER}

This report was prepared as an account of work sponsored by an agency of the United States Government. Neither the United States Government nor any agency Thereof, nor any of their employees, makes any warranty, express or implied, or assumes any legal liability or responsibility for the accuracy, completeness, or usefulness of any information, apparatus, product, or process disclosed, or represents that its use would not infringe privately owned rights. Reference herein to any specific commercial product, process, or service by trade name, trademark, manufacturer, or otherwise does not necessarily constitute or imply its endorsement, recommendation, or favoring by the United States Government or any agency thereof. The views and opinions of authors expressed herein do not necessarily state or reflect those of the United States Government or any agency thereof. 


\section{DISCLAIMER}

Portions of this document may be illegible in electronic image products. Images are produced from the best available original document. 


\section{DISCLAIMER}

This book was prepared as an account of work sponsored by an agency of the United States Government. Neither the United States Government nor any agency thereof, nor any of their employees, makes any warranty, express or implied, or assumes any legal liability or responsibility for the accuracy, completeness, or usefulness of any information, apparatus, product, or process disclosed, or represents that its use would not infringe privately owned rights. Reference herein to any specific commercial product, process, or service by trade name, trademark, manufacturer, or otherwise, does not necessarily constitute or imply its endorsement, recormendation, or favoring by the United States Guver imilent or any agency thereof. The views and opinions of authors expressed herein do not necessarily state or reflect those of the United States Government or any agency thereof. 


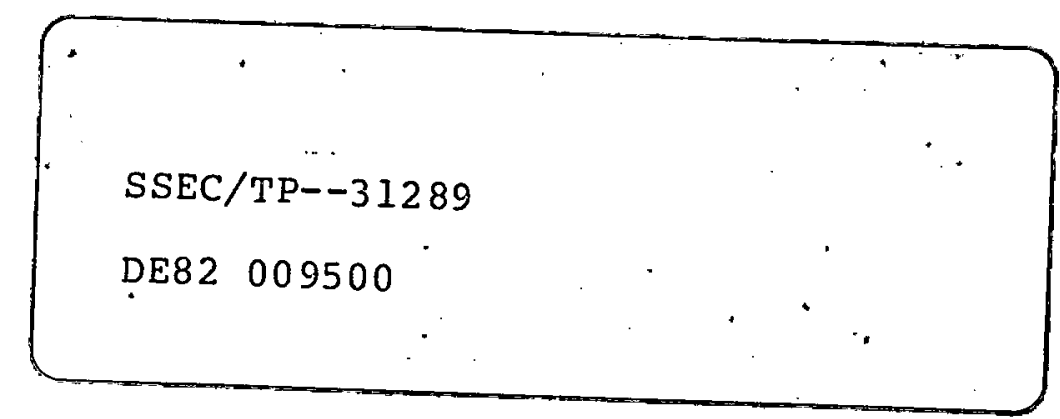

\section{ABSTRACT}

This report outlines key tax policies relevant to commercial solar energy applications. Included are certain changes in depreciation rules and small business federal income tax percentages that were part of the recently enacted Economic Recovery Tax Act of 1981. Al so, the regulations for business investment and energy tax credits are explained. An example of the effects of the new depreciation schedule on a solar industrial process heat system is given.

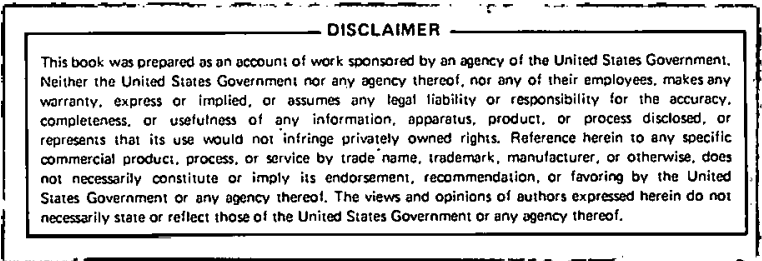




\section{TABLE OF CONTENTS}

\section{Page}

List of Tables.............................. $i i_{i}$

I. Introduction..................... 1

II. The Accelerated Cost Recovery System........ 1

III. An Example....................... 3

IV. Investment Tax Credits............... 7

V. Reductions in Corporate Tax Rates.......... 7

VI. Business Energy Tax Credits............. 7

VII. $\quad$ Summary............................ 9 
LIST OF TABLES

Page

1. DEPRECIATION SCHEDULE FOR PROPERTY PLACED IN SERVICE,

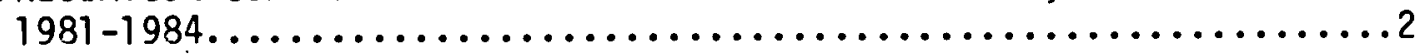

2. DEEPRECIATION SCHEDULE FOR PROPERTY PLACED IN SERVICE IN 1985.

3. DEPRECIATION SCHEDULE FOR PROPERTY PLACED IN SERVICE

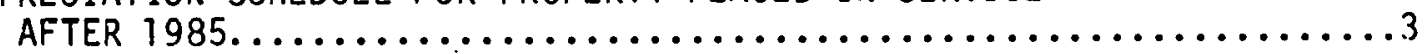

4. IMPACT OF ACCELERATED COST RECOVERY SYSTEM (ACRS) ON SOLAR IPH EXAMPLE..............................

5. ASSUMPTIONS FOR SOLAR IPH EXAMPLE. $\ldots \ldots \ldots \ldots \ldots \ldots \ldots \ldots \ldots \ldots \ldots$

6. AFTER-TAX CASH FLON FOR IPH EXAMPLE WITH OLD RULES............

7. AFTER-TAX CASH FLOW FOR IPH EXAMPLE WITH NEW ACRS ............. 


\section{Introduction}

The Economic Recovery Tax Act of 1981 represents one of the most sweeping changes in taxation policy in recent history. The tax cut legislation is designed to increase savings and investment. The legislation includes the Accelerated Cost Recovery System (ACRS) which essentially replaces the useful life depreciation rules that have been used over the last fifty years or so. The ACRS reduces the impact of inflation by significantly accelerating the recovery of capital expenditures. This paper will outline the ACRS as it applies to commercial solar equipment and in broad terms address the impact the new law will have on the economic feasibility of solar energy for businesses. This paper will also explain the investment tax credit and the reduction of the income tax rate for small businesses. In addition, the business energy tax credits available to solar and related renewable energy producing or conserving equipment are described.

\section{The Accelerated Cost Recovery System}

The Accelerated Cost Recovery System (ACRS) represents a major change in tax accounting for capital expenditures. Depreciation rules before the ACRS were based on the "useful life" concept, whereby the asset was depreciated over its useful life according to one of three depreciation methods (straight line, declining balance, and sum-of-the-years-digits). ACRS removes the direct link between useful life and depreciation recovery period. Under ACRS, depreciable assets qualify to be depreciated over one of four recovery periods, either three years, five years, ten years, or fifteen years. The useful 1 ife of the asset is a factor in determining which recovery period is used, but it is not the critical factor in determining how many years the asset can.be depreciated. Salvage value is also disregarded in computing ACRS allowances.

To qualify for recovery deductions under ACRS, capital expenditures must be for "recovery property," or tangible property used in a business or held for the production of income. Strict definitions can be found in the Internal Revenue Code. ACRS applies only to recovery property placed in service by the taxpayer during or after 1981. There are different depreciation allowance schedules for property placed in service during 1981-1984, 1985, and after 1985. These schedules are 1 isted in Tables 1,2 , and 3. 
Tab1e 1. DEPRECIATION SCHEDULE FOR PROPERTY PLACED IN SERVICE, 1981-1984

The applicable percentage for the class of property is:

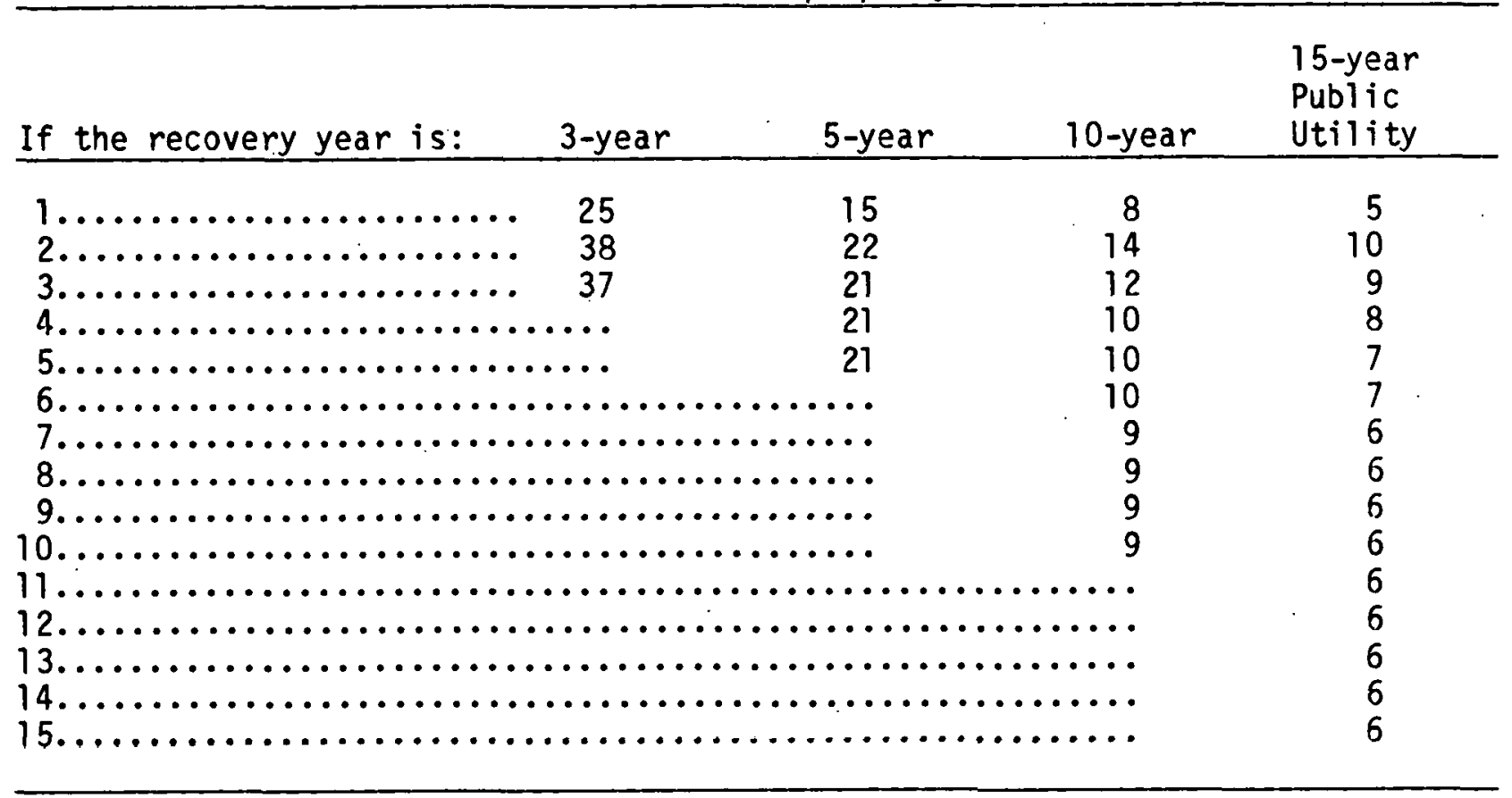

Table 2. DEPRECIATION SCHEDULE FOR PROPERTY PLACED IN SERVICE IN 1985

The applicable percentage for the class of property is:

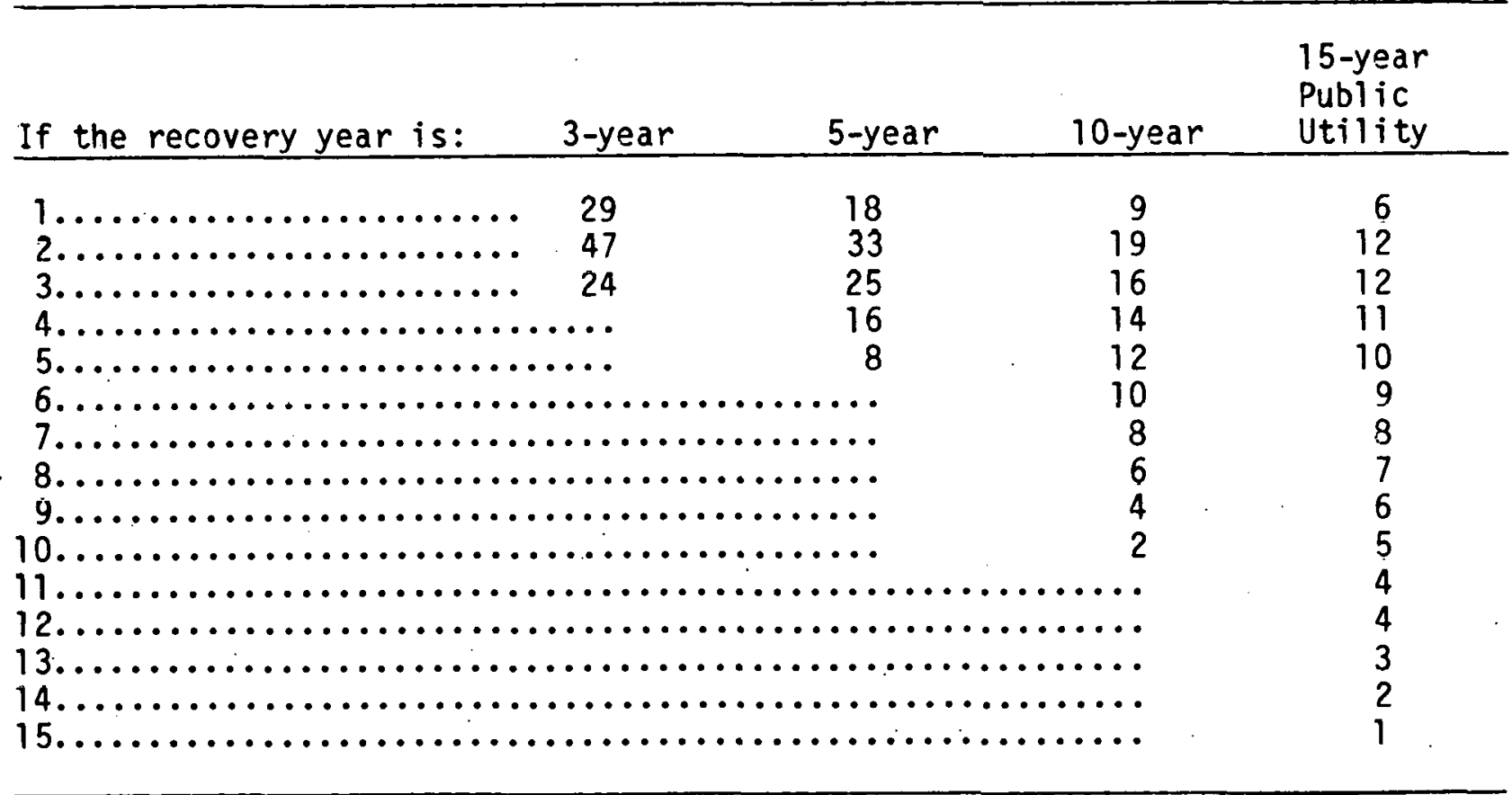


Table 3. DEPRECIATION SCHEDULE FOR PROPERTY PLACED IN SERVICE AFTER 1985

The applicable percentage for the class of property is:

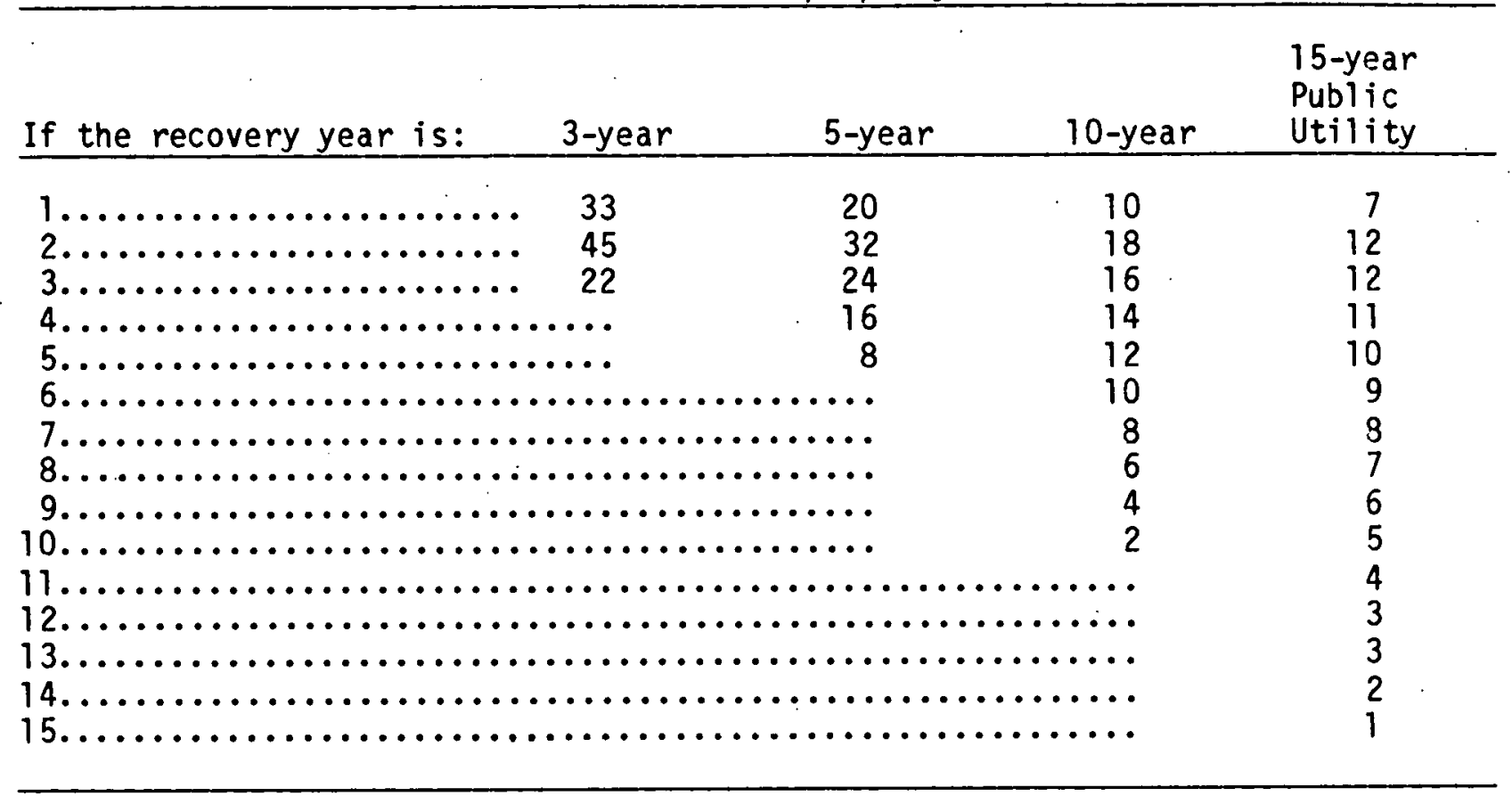

Through discussions with the Internal Revenue Service and readings of the Internal Revenue Code and Economic Recovery Tax Act of 1981: Law and Explanation by Commerce Clearing House, Inc., and from Economic Recovery Tax Act of 1981: An Analysis of the New Legislation, by Arthur Young and Company, it appears that solar water heaters for commercial operations such as car washes, laundromats, motels and solar industrial process heat equipment apply for the 5-year recovery period. There exist some questions as to solar equipment for heating and cooling of commercial buildings, since heating and cooling equipment is generally considered a structural component, not an integral part of the business, and therefore does not anply for the 5-ycar recovery period.

\section{An Example}

In order to illustrate the effects of the ACRS on the economics of solar industrial process heat applications, an example is presented in Tables 4,5 , 5, and 7. The net effect of the new depreciation schedule is shown in Table 4 by the change in two indicators of financial attractiveness, net present value and internal rate of return. The assumptions for this example are given in Table 5, and detailed cash flows are presented in Tables 6 (01d depreciation rules) and 7 (ACRS rules). When the ACRS depreciation method is used, the cash flow is improved in the early years. 
Table 4. IMPACT OF ACCELERATED COST RECOVERY SYSTEM (ACRS) ON SOLAR IPH EXAMPLE

Indicators of Financial Value

- Net Present Value

- Internal Rate of Return

Net Present Value*

\begin{tabular}{|c|c|c|}
\hline $\begin{array}{l}\text { Discount } \\
\text { Rate }\end{array}$ & $\begin{array}{l}\text { Solar IPH Exar } \\
\text { Straight-Line } \\
\text { Depreciation }\end{array}$ & $\begin{array}{l}\text { with: } \\
\text { New Rules- } \\
\text { ACRS }\end{array}$ \\
\hline $\begin{array}{l}10 \% \\
15 \% \\
20 \%\end{array}$ & $\begin{array}{r}\$ 25,416 \\
3,183 \\
-6,362\end{array}$ & $\begin{array}{r}\$ 31,641 \\
10,426 \\
1,262\end{array}$ \\
\hline
\end{tabular}

* The higher the Net Present Value, the more attractive the investment is. The discount rate is the company's cost of capital or opportunity cost for using funds in one project versus another. Given a company's discount rate, any investment with a positive Net Present Value is financially attractive.

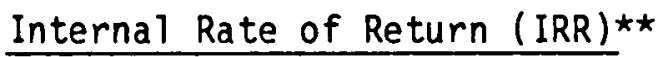

Solar IPH Example with:

\begin{tabular}{l}
$\begin{array}{l}\text { Straight Line New Rules- } \\
\text { Depreciation }\end{array}$ \\
\hline
\end{tabular}

IRR

$16.2 \%$

$.21 .2 \%$

** The internal rate of return is essentially compound interest in reverse, in that it discounts the cash flows arising from an investment at an interest rate at which they exactly equal the present value of the initial investment. Internal rates of return should be compared among similar investments with equal periods of economic evaluation. 
Table 5. ASSUMPTIONS FOR SOLAR IPH EXAMPLE

Solar IPH System Cost

Amount of Equity Financed (Down Payment)

$\$ 100,000$

30,000

Loan Interest Rate

Loan Period

Solar IPH System Life/Economic Evaluation Period

Federal 10\% Investment plus 15\% Business Energy Tax Credits

Annual Natural Gas Savings

Current Cost of Natural Gas

Projected Price Increases for Natural Gas*

Years 1 to 10

Years 11 to 20

10 years

20. years

$25 \%$

800 MMBtu

$\$ 5.50 / M M B t u$

$20.5 \%$

$17.5 \%$

Operations and Maintenance (O\&M) Expense (\% of System Cost)

Projected Increases in 0\&M Expense (Annual \%)

$0.02 \%$

Corporate Federal Income Tax Rate

$12.2 \%$

Depreciation Recovery Period: 01d Rules, Straight Line New Rul@s, ACRS

$46 \%$

10 years

5 years

* Source: Chase Econometrics, "Energy Analysis Quarterly," May 1981 . 
Table 6. AFTER-TAX CASH FLOW FOR IPH EXAMPLE WITH OLD RULES

\begin{tabular}{|c|c|c|c|c|c|c|c|}
\hline Year & $\begin{array}{l}\text { Loan } \\
\text { Payment }\end{array}$ & $\begin{array}{l}\text { Tax } \\
\text { Savings }\end{array}$ & $\begin{array}{l}0 \& M \\
\text { Expense }\end{array}$ & $\begin{array}{l}\text { Fuel } \\
\text { Savings }\end{array}$ & $\begin{array}{l}\text { Od Law: } \\
\text { Straight } \\
\text { Line } \\
\text { Depreciation }\end{array}$ & $\begin{array}{l}\text { Net } \\
\text { Annual } \\
\text { Cash Flow }\end{array}$ & $\begin{array}{c}\text { Cumulative } \\
\text { Net Cash } \\
\text { Flow }\end{array}$ \\
\hline $\begin{array}{l}0 \\
1 \\
2 \\
3 \\
4 \\
5 \\
6 \\
7 \\
8 \\
9 \\
10 \\
11 \\
12 \\
13 \\
14 \\
15 \\
16 \\
17 \\
18 \\
19 \\
20\end{array}$ & $\begin{array}{l}-30,000^{\star} \\
-15,026 \\
-15,026 \\
-15,026 \\
-15,026 \\
-15,026 \\
-15,026 \\
-15,026 \\
-15,026 \\
-15,026 \\
-15,026\end{array}$ & $\begin{array}{c}25,000^{* \hbar} \\
5,474 \\
5,230 \\
4,944 \\
4,609 \\
4,217 \\
3,759 \\
3,223 \\
2,595 \\
1,863 \\
1,004\end{array}$ & $\begin{array}{l}-920 \\
-1,032 \\
-1,158 \\
-1,299 \\
-1,458 \\
-1,635 \\
-1,835 \\
-2,059 \\
-2,311 \\
-2,593 \\
-2,909 \\
-3,254 \\
-3,662 \\
-4,109 \\
-4,610 \\
-5,172 \\
-5,803 \\
-5,511 \\
-7,305 \\
-3,197\end{array}$ & $\begin{array}{l}2,024 \\
2,439 \\
2,939 \\
3,541 \\
4,267 \\
5,142 \\
6,195 \\
7,457 \\
8,997 \\
10,842 \\
12,739 \\
14,959 \\
17,588 \\
20,665 \\
24,283 \\
28,532 \\
33,525 \\
39,392 \\
46,286 \\
54,386\end{array}$ & $\begin{array}{l}4,600 \\
4,600 \\
4,600 \\
4,600 \\
4,600 \\
4,600 \\
4,600 \\
4,600 \\
4,600 \\
4,500\end{array}$ & $\begin{array}{l}-5,000 \\
-3,848 \\
-3,789 \\
-3,701 \\
-3,575 \\
-3,400 \\
=3,161 \\
-2,842 \\
-2,422 \\
-1,877 \\
-1,173 \\
9,830 \\
11,705 \\
13,926 \\
16,557 \\
19,673 \\
23,350 \\
27,722 \\
32,881 \\
38,990 \\
45,189\end{array}$ & $\begin{array}{r}-5,000 \\
-3,848 \\
-12,637 \\
-15,338 \\
-19,913 \\
-23,313 \\
-26,474 \\
-29,315 \\
-31,738 \\
-33,615 \\
-34,783 \\
-24,958 \\
-13,253 \\
673 \\
17,230 \\
36,903 \\
50,253 \\
87,995 \\
120,865 \\
159,845 \\
205,035\end{array}$ \\
\hline
\end{tabular}

Table 7. AFTER-TAX CASH FLOW FOR IPH EXAMPLE WITH NEW ACRS

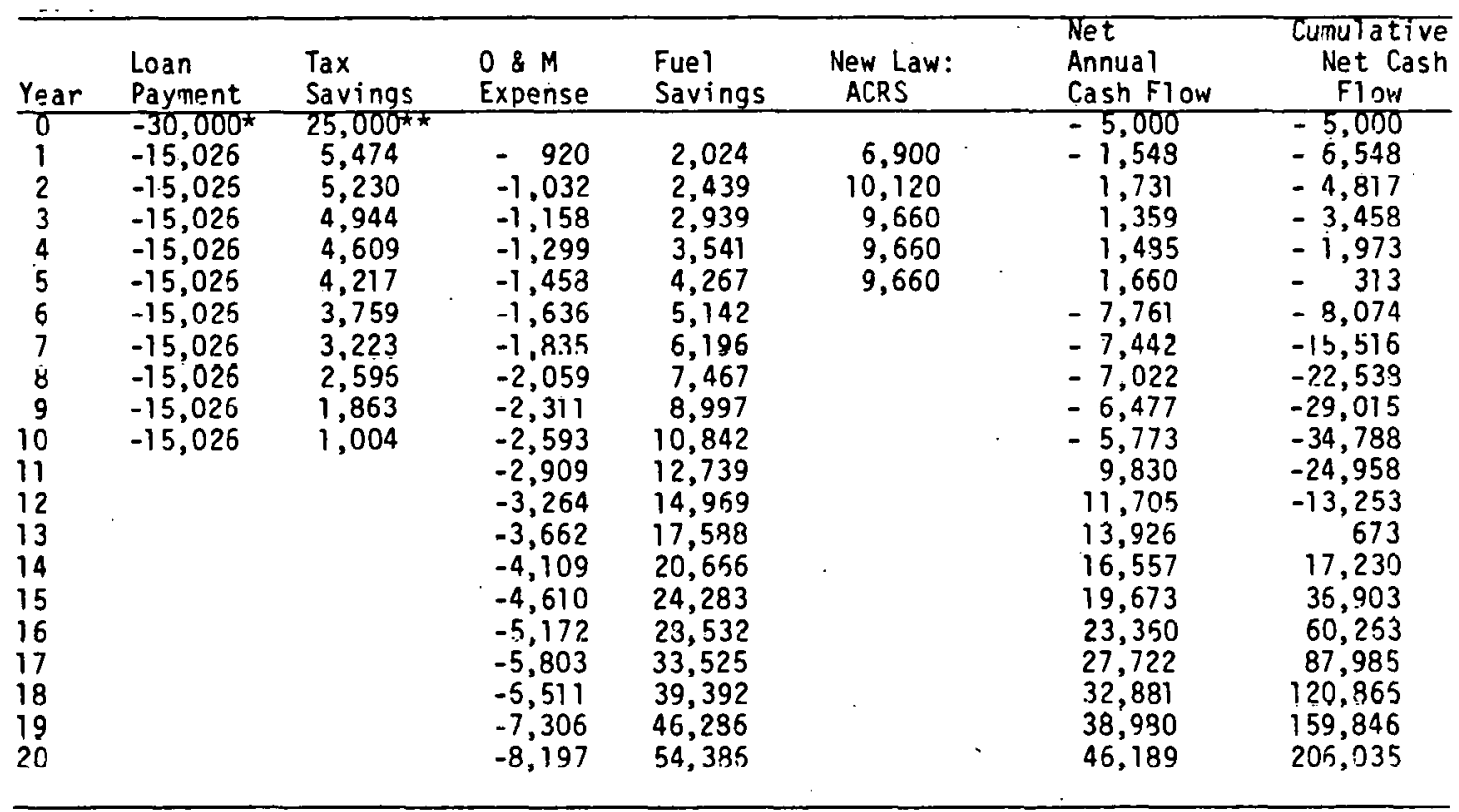

\footnotetext{
*Down Payment

$\star \star T a x$ Credit
} 


\section{Investment Tax Credits}

The eligibility requirements for the investment tax credit have also been changed from the useful life concept to the ACRS recovery period. For eligible 15-year public utility, 10-year, or 5-year property, 100 percent of the investment qualifies for the investment credit. For 3-year recovery property, only 60 percent of the investment qualifies for the credit.

The regular investment credit percentage is 10 percent of the cost of the investment. There is a Timitation on the amount of investment tax credit that can be claimed in a particular year, based on the amount of tax liability. A company can claim 10\% of the investment cost as tax credit, or $\$ 25,000$ plus $80 \%$ of the company's tax liability in 1981 over $\$ 25,000$, whichever is less. This percentage is increased to $90 \%$ in 1982 and thereafter. Any unused tax credit can be an investment tax credit carryback 3 years or carryover 7 years.

\section{Reductions in Corporate Tax Rates}

Incentives for small businesses were included in the Act in the form of reductions in the corporate tax rates for the bottom two corporate taxable income brackets (below $\$ 50,000)$. The reductions begin after 1981 .

\begin{tabular}{|c|c|c|c|c|}
\hline Taxable Ir & ncome & $\begin{array}{l}\text { 01d Law } \\
1981 .\end{array}$ & \multicolumn{2}{|c|}{$1982 \quad 1983$ and after } \\
\hline $\begin{array}{r}0 \\
25,001 \\
50,001 \\
75,001 \\
100,001\end{array}$ & $\begin{array}{r}-\quad 25,000 \\
-\quad 50,000 \\
-\quad 75,000 \\
-\quad 100,000 \\
+\quad\end{array}$ & $\begin{array}{l}17 \% \\
20 \\
30 \\
40 \\
46\end{array}$ & $\begin{array}{l}16 \% \\
19 \\
30 \\
40 \\
46\end{array}$ & $\begin{array}{l}15 \% \\
18 \\
30 \\
40 \\
46\end{array}$ \\
\hline
\end{tabular}

The maximum tax for a corporation with taxable income of $\$ 50,000$ in 1981 would be $\$ 9,250$, in 1982 it would equal $\$ 8,750$, and in 1983 and thereafter the tax would be $\$ 7,750$.

\section{Business Energy Tax Crédils}

The business energy tax credits described here relate to solar energy equipment, although the tax credits are not specifically part of the Economic Recovery Tax Act of 1981. The explanation is provided in order to present a clear picture of the entire taxation matter as related to solar commercial development.

The tax credits available to businesses for investments in energy producing or conserving equipment vary according to the type of property. Strict definitions determine what equipment qualifies for which property class, and the following descriptions are general in nature. Also, only the property classes that apply to solar energy equipment are described. 
Al ternative Energy Property

Property that uses one of the alternative fuels, or is used to produce alternative fuels from an alternative substance, is alternative energy property. Alternative fuels generally refers to fuels derived from sources other than oil or natural gas.

Type of Property

General rule

Geothermal equipment

Ocean thermal property

Biomass property

\begin{tabular}{c} 
Credi \\
\hline $10 \%$ \\
$15 \%$ \\
$15 \%$ \\
$10 \%$
\end{tabular}

Acquired

on or after

Oct. 1,1978

Jan. 1,1980

Jan. 1,1980

Oct. 1,1978
Placed in service before

Dec. 31,1982

Dec. 31,1985

Dec. 31, 1985

Dec. 31,1985

- Solar or Wind Energy Property

Equipment that uses solar or wind energy to generate electricity, heat, cool, or provide hot water for use in a structure as well as solar-generated process heat for industrial, commercial or agricultural purposes. This property includes only active systems.

$\begin{array}{ll}\text { Credit: } & 15 \% \\ \text { Expenditure before: } & 1986 \\ \text { Placed in Service before: } & 1986\end{array}$

- Hydroelectric Generating Property

Applies to qualifying investments in small-scale hydroelectric property, beginning January 1, 1980, and ending December 31, 1985, with a three-year additional period for projects for which an application has been docketed by the Federal Energy Regulatory Commission before 1986.

Credit:

$11 \%$ for sites with less than $25 \mathrm{MW}$

As capacity increases from 25 to $125 \mathrm{MW}$, the credit is phased out. Between 25 and $100 \mathrm{MW}$, the qualified investment is reduced by a fraction equal to 25 divided by the total installed capacity up to $100 \mathrm{MW}$. As total capacity rises from 100 to $125 \mathrm{MW}$, the credit is phased out entirely.

- Cogeneration Equipment

Applies to property that is an integral part of a system for using the same fuel to produce both qualified energy and electricity at an industrial or commercial facility, and the property must result in an increase in the capacity of the system.

The system must not use oil, natural gas, or a product of oil or natural gas as a fuel, or, if it uses such fuels for startup, backup, or flame stabilization purposes, such fuels must not comprise more than 20 percent of the fuel consumed by the system.

Credit:

Available:
$10 \%$

through 1982 
VII. Summary

The tax policy changes incorporated in the Economic Recovery Tax Act of 1981 improve the economic attractiveness of commercial solar equipment, but the changes improve the attractiveness of all capital investment opportunities as well. The relative situation between solar and conventional systems will not change significantly until solar system costs come down and/or conventional fuel prices rise further. Also, the slight reduction in corporate income tax rates for small businesses will not significantly change the attractiveness of solar systems for commercial enterprises. 